\title{
SIKAP MAHASISWA MEMANFAATKAN TEKNOLOGI INFORMASI DAN KOMUNIKASI DALAM PEMBELAJARAN TERBUKA DAN JARAK JAUH
}

\author{
Idha Farida (idha@ut.ac.id) \\ Ernik Yuliana \\ Faculty of Matemathic and Science Universitas Terbuka \\ Jl. Cabe Raya Pondok Cabe, Pamulang \\ Tangerang Selatan, Indonesia
}

\begin{abstract}
Utilization of information and communication technology (ICT) in open and distance education is very important. Universitas Terbuka (UT-The Indonesia Open University) gradually began developing and using ICT applications for a variety of purposes, both academic and administrative. In the academic services, UT provides learning materials specifically designed for independent learning. The students can using learning materials provided by UT through the internet such as online tutorial (tuton), web supplement, internet television (I-TV), and online exercise independent (LM-Online). The objectives of the research were: (i) to describe students' attitude for using information and communication technology in open and distance learning, and (ii) to describe the relationship between the students characteristics with their attitude for using information and communication technology in open and distance learning. This research was conducted with the survey methods and observations in the Regional Office (UPBJJ-UT) in Serang dan Bengkulu. The 52 students samples were randomly selected as respondents. The data were analyzed through Spearman rank correlation test. The result showed students' attitude for using information and communication technology in open and distance learning is pretty good. The result showed educational students background were significantly correlated with their attitude for using web supplement and I-TV. A student region of residence were significantly correlated with their attitude for using I-TV. There was also a significant correlation between the availability of internet facilities and computer ownership with their attitudes for using tuton, web supplement and I-TV.
\end{abstract}

Keywords: information and communication technology, open and distance learnin, students' attitude

\begin{abstract}
ABSTRAK
Pemanfaatan teknologi informasi dan komunikasi ( TIK ) dalam pendidikan terbuka dan jarak jauh sangat penting. Universitas Terbuka (UT) secara bertahap mulai mengembangkan dan menggunakan aplikasi ICT untuk berbagai keperluan, baik akademik dan administratif. Dalam pelayanan akademik, UT menyediakan bahan ajar yang dirancang khusus untuk belajar mandiri. Para mahasiswa dapat menggunakan bahan pembelajaran yang diberikan oleh UT melalui internet seperti tutorial secara online (Tuton), suplemen web , televisi internet (I- TV), dan latihan mandiri online (LM - Online). Tujuan dari penelitian ini adalah: (1) untuk menggambarkan sikap mahasiswa untuk menggunakan teknologi
\end{abstract}


informasi dan komunikasi dalam pembelajaran terbuka dan jarak jauh, dan (2) untuk menggambarkan hubungan antara karakteristik mahasiswa dengan sikap mereka dalam menggunakan teknologi informasi dan komunikasi pada media pembelajaran terbuka dan jarak jauh. Penelitian ini dilakukan dengan metode survei dan pengamatan di Kantor Wilayah (UPBJJ-UT) di Serang dan Bengkulu. Sampel sebanyak 52 mahasiswa dipilih secara acak sebagai responden. Data dianalisis melalui uji korelasi Rank Spearman. Hasil penelitian menunjukkan sikap mahasiswa menggunakan teknologi informasi dan komunikasi dalam pembelajaran terbuka dan jarak cukup bagus. Selanjutnya hasil penelitian menunjukkan latar belakang pendidikan mahasiswa secara signifikan berkorelasi dengan sikap mereka untuk menggunakan suplemen web dan I-TV. Tempat tinggal mahasiswa secara signifikan berkorelasi dengan sikap mereka untuk menggunakan I- TV. Ada juga hubungan yang signifikan antara ketersediaan fasilitas internet dan kepemilikan komputer dengan sikap mereka untuk menggunakan Tuton, suplemen web dan I- TV .

Kata kunci: informasi dan komunikasi, pembelajaran terbuka dan jarak jauh, sikap mahasiswa

Universitas Terbuka (UT) sebagai penyelenggara sistem pendidikan tinggi terbuka jarak jauh (PTTJJ) menuntut mahasiswanya untuk dapat belajar secara mandiri. Sebagai bentuk layanan untuk membantu proses belajar mahasiswa secara mandiri, UT memberikan beberapa fasilitas sebagai sumber belajar di samping sumber belajar utama yaitu bahan ajar cetak (BAC). Layanan untuk membantu proses belajar mahasiswa tersebut selanjutnya disebut dengan layanan akademik. Tujuan penyediaan layanan akademik adalah membantu mahasiswa dalam menjalani proses belajarnya. Melalui proses belajar mandiri, terbimbing, dan pemanfaatan berbagai sumber belajar sebagai satu kesatuan utuh dalam sistem pembelajaran, diharapkan mahasiswa dapat melakukan proses belajar yang optimum dengan hasil yang memuaskan.

Layanan akademik yang disediakan oleh UT di antaranya adalah tutorial, praktikum, bimbingan akademik, LM online, internet-TV, web suplemen, pengumuman ujian, sistem ujian online (SUO), dan layanan lainnya. Beberapa layanan akademik sudah disediakan dalam bentuk online, untuk memudahkan mahasiswa yang tempat tinggalnya jauh dari kantor Unit Program Belajar Jarak Jauh Universitas Terbuka (UPBJJ-UT). Dengan demikian, mahasiswa dapat mengakses layanan akademik kapan saja dan di mana saja tanpa harus meluangkan waktu untuk datang ke kantor UPBJJ-UT.

Pemanfaatan teknologi informasi dan komunikasi (TIK) dalam sistem Pendidikan Tinggi Terbuka Jarak Jauh (PTTJJ) adalah keharusan. Seiring dengan masuknya teknologi berbasis internet ke Indonesia pada pertengahan tahun 1990-an, UT secara bertahap mulai mengembangkan dan menggunakan aplikasi TIK untuk berbagai keperluan, baik akademik maupun administrasi. Perkembangan pemanfaatan TIK oleh UT secara signifikan tampak dengan diluncurkannya portal UT online yang mulai dikembangkan pada tahun 2001.

Menurut Belawati (2003), sejak tahun 1995, ketika internet sudah masuk ke Indonesia, UT kemudian mulai mengembangkan bahan ajar suplemen dalam bentuk file-file HTML dengan menggunakan perangkat lunak frontpage. Pada saat bersamaan UT juga mulai mengembangkan bahan ajar suplemen dalam format Computer Assisted Instruction (CAI) yang juga didistribusikan kepada mahasiswa melalui internet. Bahan-bahan ajar ini kemudian diintegrasikan dengan program- 
program audio/video yang telah dimiliki UT. Secara terpisah, program-program video tersebut juga di up load ke internet sehingga dapat dilihat/ditonton oleh mahasiswa di warnet-warnet.

Saat ini, UT banyak mengembangkan program yang berbasis TIK. Berdasarkan Renstra UT 2010-2021, TIK dapat dimanfaatkan untuk online learning (termasuk tutorial online) pada pendidikan jarak jauh antara lain: course website, audiovideo capture via web, web conference, dan penggunaan telepon genggam untuk mengunduh materi. Dengan adanya course website, mahasiswa dan/atau dosen mendapatkan berbagai keuntungan di antaranya mahasiswa dapat mengakses materi website kapan saja dan di mana saja. Dosen juga dapat mengembangkan website sendiri untuk mata kuliahnya. Saat ini terdapat banyak sumber yang sudah dikembangkan dan dapat direvisi untuk dipergunakan kembali.

Meskipun TIK memiliki peranan yang sangat penting dalam penyelenggaraan sistem PTTJJ, namun dalam aplikasinya di UT masih terdapat permasalahan, terutama dari sisi kesiapan mahasiswa dalam menggunakan TIK. Beberapa hasil penelitian menunjukkan bahwa akses mahasiswa UT dalam mengakses layanan online masih rendah. Temuan Sukarsih (2005) mengenai pemanfaatan layanan UT Online oleh mahasiswa tergolong kurang (26,1\%). Penelitian Padmo dan Julaeha (2007) mengenai penilaian mahasiswa dalam menggunakan jaringan internet termasuk dalam kategori sedang, artinya mereka cukup mampu dalam menggunakan jaringan internet. Temuan Iriani (2010) mengenai jumlah mahasiswa UT yang memanfaatkan fasilitas SUO kurang dari $2 \%$ dari jumlah mahasiswa non-pendidikan dasar di UPBJJ-UT Surabaya. Adapun Yuliana dan Wardiny (2011) menemukan sebagian besar (44,7\%) mahasiswa Program Studi Agribisnis FMIPAUT mempunyai frekuensi akses yang rendah terhadap tutorial online.

Beranjak dari permasalahan rendahnya akses mahasiswa terhadap layanan akademik online, maka perlu adanya identifikasi sikap mahasiswa S1 Agribisnis FMIPA-UT memanfaatkan TIK dalam pembelajarannya. Tujuan penulisan artikel ini adalah: (1) mendeskripsikan sikap mahasiswa memanfaatkan TIK dalam pembelajaran terbuka dan jarak jauh, dan (2) mendeskripsikan hubungan antara karakteristik mahasiswa dengan sikap mereka memanfaatkan TIK dalam pembelajaran terbuka dan jarak jauh.

\section{METODE}

Penelitian bersifat deskriptif kuantitatif dengan tujuan untuk menguraikan tentang perilaku mahasiswa dalam pemanfaatan TIK untuk mendukung kegiatan pembelajaran mandiri. Responden dipilih secara simpel random sampling. Populasi mahasiswa adalah seluruh mahasiswa S1 Agribisnis di UPBJJ-UT Serang dan UPBJJ-UT Bengkulu. Sampel dipilih sebanyak 52 orang mahasiswa.

Data yang dikumpulkan berupa data primer dan data sekunder. Pengumpulan data melalui pengiriman kuesioner kepada mahasiswa dan wawancara melalui telepon dan tatap muka. Kuesioner disebarkan kepada 80 mahasiswa namun yang menjadi responden adalah adalah 52 mahasiswa. Data dianalisis secara deskriptif dan inferensial. Korelasi Rank Spearman digunakan untuk melihat hubungan antara karakteristik internal dan eksternal mahasiswa dengan sikap mahasiswa memanfaatkan TIK dalam pembelajaran terbuka dan jarak jauh.

\section{HASIL DAN PEMBAHASAN}

Dalam dunia pendidikan, keberadaan sistem informasi dan komunikasi merupakan salah satu komponen yang tidak dapat dipisahkan dari aktivitas pendidikan. Sebuah lembaga pendidikan harus memiliki komponen-komponen yang diperlukan untuk menjalankan operasional pendidikan, seperti siswa, sarana dan prasarana, struktur organisasi, proses, sumber daya manusia (tenaga 
pendidik), dan biaya operasi. Sedangkan sistem komunikasi dan informasi terdiri atas komponenkomponen pendukung lembaga pendidikan untuk menyediakan informasi yang dibutuhkan pihak pengambil keputusan saat melakukan aktivitas pendidikan (Pustekkom, 2006).

Berdasarkan data di www.internetworldstats.com (2012), pengguna internet di Indonesia tumbuh $2.750 \%$ dalam 10 tahun terakhir. Pada tahun 2011 total pengguna internet mencapai 55 juta. Namun demikian, jika dibandingkan dengan total penduduk Indonesia (245,6 juta jiwa), maka jumlah pengguna internet tersebut masih relatif kecil atau hanya sekitar 22,4 \%.

TIK telah memungkinkan terjadinya individuasi, akselerasi, pengayaan, perluasan, efektivitas dan produktivitas pembelajaran yang akan meningkatkan kualitas pendidikan sebagai infrastruktur pengembangan SDM secara keseluruhan. Melalui penggunaan TIK setiap siswa akan terangsang untuk belajar maju berkelanjutan sesuai dengan potensi dan kecakapan yang dimilikinya.

Pembelajaran dengan menggunakan TIK menuntut kreativitas dan kemandirian diri sehingga memungkinkan mengembangkan semua potensi yang dimilikinya (Kusumah, 2010).

Berdasarkan hasil temuan Smeureanu dan Isaila (2011) disimpulkan bahwa TIK merupakan alat yang berguna untuk mengembangkan cara berpikir dan perilaku baru yang memungkinkan tenaga pengajar untuk memenuhi setiap kebutuhan baru. Hal ini juga didukung oleh penelitian Gokalp (2010) mengenai efek teknologi informasi pada mahasiswa, yang menunjukkan bahwa teknologi informasi secara positif mempengaruhi keberhasilan akademis siswa.

Dalam proses belajar mengajar, model pendidikan TIK lebih menitik beratkan kemampuan peserta didik secara individual terhadap materi pembelajaran yang telah disusun ke tingkat kesiapan sehingga peserta didik mampu memperlihatkan perilaku yang sesuai dengan yang diharapkan. Melalui teknologi, materi pelajaran dan metodologi pengajaran ditetapkan dengan dukungan teknologi. Singkatnya secara esensial teknologi pengajaran dapat menggantikan peran pendidik dan peserta dapat berperan aktif sebagai pelatih yang mempelajari semua data dan keterampilan yang berguna (Palupiningdyah dan Widiyanto, 2011).

\section{Karakteristik Internal Responden}

Karakteristik internal yang dibahas dalam penelitian ini adalah umur, pendidikan formal, pekerjaan, dan perndapatan perbulan responden. Sebaran karakteristik internal responden dapat dilihat pada Tabel 1.

Pada Tabel 1 terlihat bahwa umur responden sebagian besar berada pada kategori dewasa akhir yakni sebesar 46,1\%. Menurut Pikunas (Yuliana, 2007), umur manusia pada kategori dewasa akhir mempunyai ciri kurang dapat menerima kemajuan ilmu pengetahuan dan teknologi (iptek) dan teknologi dalam menjalankan kegiatan sehari-hari. Mereka lebih banyak menerima keadaan yang ada dan sulit sekali diperkenalkan kepada penemuan (iptek) yang baru.

Pendidikan formal responden sebagian besar berada pada kategori SMA yakni sebesar $84,6 \%$. Hal ini menandakan bahwa ketertarikan lulusan SMA terhadap Program Studi (PS) Agribisnis cukup besar, tetapi bukan fresh graduate dari SMA. Mereka sudah menempuh pendidikan terlebih dahulu di jenjang D3, tetapi belum lulus dan memilih untuk melanjutkan di PS Agribisnis. Terbukti dengan umur mereka yang didominasi oleh dewasa akhir. Temuan ini berbeda dengan hasil penelitian Yuliana dan Wardini (2011), bahwa mahasiswa PS Agribisnis UT didominasi oleh alumni D3 yang kebanyakan berprofesi sebagai penyuluh pertanian. Banyaknya alumni SMA yang masuk ke PS Agribisnis memberikan harapan yang baik bagi PS, karena alumni SMA mulai tertarik untuk belajar ilmu agribisnis. Hal ini sejalan dengan tujuan UT untuk meningkatkan jumlah mahasiswa nonguru yang berasal dari alumni SMA (Renstra UT 2010-2021). Jadi, PS Agribisnis tidak hanya 
bergantung kepada alumni D3 Penyuluhan Pertanian yang sudah bekerja sebagai penyuluh, tetapi berpeluang lebih banyak untuk menerima alumni SMA. Alumni SMA tersebut diharapkan kemampuannya lebih tinggi dalam menggunakan komputer dan internet dibandingkan dengan mahasiswa yang sudah bekerja. Dengan demikian, kemampuan mereka untuk mengikuti tuton tidak mengkhawatirkan lagi (Yuliana dan Wardiny, 2011).

Tabel 1. Sebaran Karakteristik Internal Responden

\begin{tabular}{|c|c|c|c|}
\hline \multirow[t]{2}{*}{ Karakteristik Internal $\left(\mathrm{X}_{1}\right)$} & \multirow[t]{2}{*}{ Rentang } & \multicolumn{2}{|c|}{ Jumlah } \\
\hline & & $\mathrm{n}$ & $(\%)$ \\
\hline \multirow{3}{*}{ Umur $\left(X_{1.1}\right)$} & Dewasa akhir (> 40 thn) & 24 & 46,1 \\
\hline & Dewasa madya (31-40 thn) & 17 & 32,7 \\
\hline & Dewasa awal (<31 thn) & 11 & 21,2 \\
\hline \multirow{2}{*}{ Pendidikan formal $\left(\mathrm{X}_{1.2}\right)$} & D3 & 8 & 15,4 \\
\hline & SMA & 44 & 84,6 \\
\hline \multirow{2}{*}{ Pekerjaan $\left(X_{1.3}\right)$} & Belum bekerja & 8 & 15,4 \\
\hline & Sudah bekerja & 44 & 84,6 \\
\hline \multirow{3}{*}{ Pendapatan perbulan $\left(X_{1.4}\right)$} & $<1$ juta & 16 & 30,8 \\
\hline & $1-2$ juta & 27 & 51,9 \\
\hline & $>2$ juta & 9 & 17,3 \\
\hline
\end{tabular}

Berdasarkan data pada Tabel 1 mengenai pekerjaan dapat diketahui bahwa sebagian besar $(84,6 \%)$ responden sudah bekerja dan mempunyai pendapatan sendiri. Bagi mahasiswa yang sudah bekerja, akses internet dapat dilakukan di tempat kerja atau di rumah dan warung internet (warnet) di luar jam kerja. Dari segi biaya akses internet di luar jam kerja, dapat dibiayai responden dengan menyisihkan sebagian pendapatannya untuk biaya akses internet. Dengan demikian, sebagian besar responden tidak bermasalah dengan biaya akses internet.

Temuan mengenai tingkat pendapatan pada Tabel 1 dapat diketahui bahwa sebagian besar responden (51,9\%) berpendapatan sebesar Rp 1.000.000-Rp 2.000.000, yang termasuk kategori sedang. Pendapatan tersebut dirasa cukup untuk memenuhi kebutuhan sehari-hari, dan membiayai akses internet. Jika mahasiswa yang sudah bekerja dapat akses internet di tempatnya bekerja, maka mereka tidak perlu mengalokasikan sebagian pendapatan untuk akses internet.

\section{Karakteristik Eksternal Responden}

Karakteristik eksternal yang dibahas dalam penelitian ini adalah wilayah tempat tinggal, kekosmopolitan, ketersediaan fasilitas internet, kepemilikan komputer pribadi/laptop, dan intensitas akses internet. Sebaran karakteristik internal responden dapat dilihat pada Tabel 2.

Sebagian besar responden $(94,2 \%)$ bertempat tinggal di luar kota UPBJJ-UT. Mahasiswa yang bertempat tinggal di luar kota UPBJJ-UT harus meluangkan waktu yang cukup banyak untuk mengurus administrasi akademik dan mahasiswa ke kantor UPBJJ-UT. Sebagai solusinya, mereka lebih baik memilih memanfaatkan internet untuk keperluan tersebut. 
Tabel 2. Sebaran Karakteristik Eksternal Responden

\begin{tabular}{|c|c|c|c|}
\hline \multirow{2}{*}{ Karakteristik Eksternal $\left(\mathrm{X}_{2}\right)$} & \multirow{2}{*}{ Rentang } & \multicolumn{2}{|c|}{ Jumlah } \\
\hline & & $\mathrm{n}$ & $(\%)$ \\
\hline \multirow{3}{*}{ Wilayah tempat tinggal $\left(X_{2.1}\right)$} & Di luar UPBJJ & 49 & 94,2 \\
\hline & Di dalam UPBJJ & 3 & 5,8 \\
\hline & $<3$ kali & 29 & 55,8 \\
\hline \multirow[t]{3}{*}{ Kekosmopolitan $\left(\mathrm{X}_{2.2}\right)$} & 4-6 kali/minqqu & 6 & 11.5 \\
\hline & $>6 \mathrm{kali} / \mathrm{minggu}$ & 17 & 32,7 \\
\hline & Tidak ada & 12 & 23,1 \\
\hline \multirow{2}{*}{ Ketersediaan fasilitas internet $\left(\mathrm{X}_{2.3}\right)$} & Rumah/warnet/kantor & 39 & 75,0 \\
\hline & Rumah, warnet, dan kantor & 1 & 1,9 \\
\hline \multirow{3}{*}{$\begin{array}{l}\text { Kepemilikan komputer pribadi/laptop } \\
\left(\mathrm{X}_{2.4}\right)\end{array}$} & Tidak ada & 26 & 50,0 \\
\hline & Ada & 26 & 50,0 \\
\hline & Tidak pernah & 17 & 32,7 \\
\hline \multirow[t]{2}{*}{ Intensitas akses internet $\left(\mathrm{X}_{2.5}\right)$} & $>2$ minggu sekali & 12 & 23,1 \\
\hline & $<2$ minggu sekali & 23 & 44,2 \\
\hline
\end{tabular}

Sebaran mengenai tingkat kekosmopolitan mahasiswa termasuk ke dalam kategori rendah, yakni sebesar $55,8 \%$. Tingkat kekosmopolitan dalam penelitian ini adalah berhubungan dengan mobilitas mahasiswa mencari informasi (sumber belajar). Temuan Pujiriyanto (Wahyono dan Pujiriyanto, 2010) menunjukkan adanya hubungan yang relatif signifikan antara siswa yang memiliki mobilitas mencari sumber dengan pemanfaatan TIK secara produktif dimana TIK cenderung dimanfaatkan untuk mencari informasi berbasis akademik. Sementara siswa yang tidak memiliki sarana penunjang TIK seperti komputer pribadi di rumah, atau koneksitas dan aksesibilitas ke jaringan internetnya rendah cenderung lebih menonjolkan apek rekreatif dan relatif rendah mobilitasnya (fisik dan non fisik) dalam mencari sumber belajar.

Akses internet oleh mahasiswa dapat dilakukan di rumah, warnet, atau kantor. Berdasarkan data pada Tabel 2 , sebagian besar responden (75\%) mempunyai fasilitas internet di rumah/warnet/kantor. Kesempatan mahasiswa akses internet di rumah memberikan keleluasaan bagi mahasiswa, baik dalam menjalankan proses akademik atau mengakses layanan administrasi. Ketersediaan fasilitas tersebut diharapkan dapat memudahkan mahasiswa dalam mengikuti proses belajar-mengajar. Sesuai dengan karakteristik UT yang menerapkan pendidikan terbuka dan jarak jauh, maka ketersediaan fasilitas internet tersebut sangat menunjang proses layanan akademik dan administrasi.

Responden penelitian sebanyak 50\% mempunyai komputer pribadi. Kepemilikan komputer (apabila dilengkapi dengan fasilitas internet) dapat meningkatkan aksesibilitas mahasiswa terhadap layanan internet untuk proses akademik dan layanan administrasi akademik. Bagi mahasiswa yang tidak mempunyai komputer di rumah, akses internet dapat dilakukan di warnet. Biaya akses tuton di warnet relatif murah dibandingkan dengan manfaat yang didapatkan oleh mahasiswa. Keberadaan komputer pribadi di rumah dapat memberikan manfaat yang cukup banyak kepada mahasiswa, 
diantaranya dapat membantu mengerjakan tugas kuliah di rumah, berkomunikasi dengan orang lain melalui e-mail atau jejaring sosial serta membuat mahasiswa melek akan teknologi.

Intensitas adalah seberapa sering waktu yang digunakan untuk melakukan sesuatu. Kaitannya dengan penelitian ini adalah seberapa sering waktu yang digunakan oleh responden untuk menggunakan internet. Berdasarkan hasil pada Tabel 2, intensitas akses internet responden tersebar pada kategori tidak pernah menggunakan sebesar $32,7 \%$ dan $<2$ minggu sekali sebesar $44,2 \%$.

Berdasarkan temuan di lapangan, sebagian responden memang belum terlalu sering menggunakan internet dalam keseharian mereka. Kendalanya adalah karena kemampuan mereka dalam menggunakan komputer yang rendah dan pengetahuan tentang internet pun rendah. Hal ini sejalan dengan temuan hasil penelitian sebelumnya oleh Yuliana \& Winata (2009) dan Susanti (2007), sebagian besar mahasiswa UT mempunyai kemampuan menggunakan komputer dan internet yang rendah.

\section{Sikap Mahasiswa Memanfaatkan TIK dalam Pembelajaran Terbuka dan Jarak Jauh}

Jaringan internet saat ini sudah dapat diakses dari daerah-daerah di luar kota besar. TIK berkembang sangat pesat dalam kuantitas maupun kualitas. Dampaknya menunjukkan bahwa penetrasi TIK dalam hampir seluruh aspek kehidupan semakin kuat. Pemerintah berkepentingan untuk merespon dampak penetrasi TIK secara bijak di sektor ekonomi, pemerontahan, maupun pendidikan. Di dunia pendidikan, pemanfaatan TIK berjalan sangat cepat dalam proses pembelajaran (Renstra UT 2010-2021).

Tabel 3. Sebaran Sikap Responden dalam Pembelajaran Jarak Jauh di UT

\begin{tabular}{|c|c|c|c|}
\hline \multirow{2}{*}{ Sikap Responden (Y) } & \multirow{2}{*}{ Rentang } & \multicolumn{2}{|c|}{ Jumlah } \\
\hline & & $\mathrm{n}$ & $(\%)$ \\
\hline \multirow{3}{*}{ Tuton } & Baik & 12 & 23,1 \\
\hline & Cukup Baik & 35 & 67,3 \\
\hline & Kurang Baik & 5 & 9,6 \\
\hline \multirow{3}{*}{ Websuplemen } & Baik & 11 & 21,2 \\
\hline & Cukup Baik & 36 & 69,2 \\
\hline & Kurang Baik & 5 & 9,6 \\
\hline \multirow{3}{*}{ I-TV } & Baik & 16 & 30,8 \\
\hline & Cukup Baik & 32 & 61,5 \\
\hline & Kurang Baik & 4 & 7,7 \\
\hline \multirow{3}{*}{ LM Online } & Baik & 8 & 15,4 \\
\hline & Cukup Baik & 38 & 73,1 \\
\hline & Kurang Baik & 6 & 11,5 \\
\hline
\end{tabular}

Perkembangan TIK seperti komputer dan teknologi komunikasi, khsususnya internet dapat digunakan untuk menjembatani informasi dan pengetahuan yang tersebar diantara yang menguasai informasi dan yang tidak. Akses terhadap komunikasi digital membantu meningkatkan akses salah satunya terhadap peluang pendidikan (Servaes, 2007). Oleh karena itu, penting bagi mahasiswa UT 
untuk mengetahui keberadaan layanan akademik agar dapat membantu meningkatkan pengetahuan mereka. Sebaran sikap responden memanfaatkan TIK dalam pembelajaran jarak jauh di UT dapat terlihat pada Tabel 2.

Berdasarkan temuan pada Tabel 3 dapat disimpulkan bahwa sikap responden dalam pembelajaran di UT yakni untuk tuton, websuplemen, I-TV dan LM Online berada pada kategori cukup baik. Responden menilai keberadaan keempat layanan akademik tersebut cukup baik dalam membantu kegiatan pembelajaran mereka. Sebaran yang terttinggi yakni pada LM Online, yakni sebesar 73,1\%. Responden merasakan LM Online dapat membantu mereka dalam melatih materimateri yang telah mereka pelajari sebelumnya. Adapun, hubungan antara karakteristik internal dan eksternal dengan sikap responden memanfaatkan TIK dalam pembelajaran dapat dilihat pada Tabel 4.

Tabel 4. Hubungan antara Karakteristik Internal dan Eksternal dengan Sikap Mahasiswa Memanfaatkan TIK dalam Pembelajaran Jarak Jauh

\begin{tabular}{llccc}
\hline \multicolumn{1}{c}{ Variabel } & \multicolumn{4}{c}{ Sikap } \\
\cline { 2 - 5 } & Tuton & Websupplemen & I-TV & LM Online \\
\hline $\begin{array}{l}\text { Karakteristik Internal } \\
\begin{array}{c}\text { Pendidikan Formal } \\
\text { Karakteristik Eksternal }\end{array}\end{array}$ & 0,178 & $0,310^{*}$ & $0,312^{*}$ & 0,265 \\
Wilayah Tempat tinggal & 0,100 & 0,116 & $0,277^{*}$ & $-0,062$ \\
Ketersediaan fasilitas internet & $0,436^{* *}$ & $0,357^{* *}$ & $0,276^{*}$ & 0,219 \\
Kepemilikan komputer & $0,436^{* *}$ & $0,357^{* *}$ & $0,276^{*}$ & 0,219 \\
\hline
\end{tabular}
Ket : * Nyata pada $a=0,05,{ }^{*}$ Nyata pada $a=0,01$

Data pada Tabel 4 menyajikan informasi mengenai karakteristik internal dan eksternal yang memiliki hubungan nyata dengan sikap mahasiswa memanfaatkan TIK dalam pembelajaran jarak jauh. Karakteristik internal yakni latar belakang pendidikan formal berhubungan nyata dengan sikap mahasiswa terhadap websuplemen dan I-TV sebagai media pembelajaran. Semakin tinggi latar belakang mahasiswa maka akan semakin baik sikapnya terhadap pemanfaatan websuplemen dan ITV sebagai media pembelajaran. Karakteristik eksternal yakni wilayah tempat tinggal responden ternyata berhubungan nyata dengan sikap mahasiswa terhadap I-TV sebagai media pembelajaran. Semakin dekat wilayah tempat tinggal mahasiswa dengan UPBJJ-UT maka akan semakin baik sikapnya terhadap pemanfaatan I-TV sebagai media pembelajaran.

Temuan karakteristik eksternal berikutnya yakni ketersediaan fasilitas internet dan kepemilikan komputer berhubungan nyata dengan sikap mahasiswa terhadap tuton, websuplemen, dan I-TV sebagai media pembelajaran. Semakin baik ketersediaan fasilitas internet dan memiliki komputer sendiri maka akan semakin baik sikapnya terhadap pemanfaatan tuton, websuplemen, dan I-TV sebagai media pembelajaran. Menurut Pribadi (2004), bahan ajar berbentuk program video dan siaran televisi telah lama digunakan sebagai sarana untuk menyampaikan isi atau materi ajar dalam penyelenggaraan PJJ. Bahan ajar video memiliki keunggulan dalam menyampaikan informasi dan pengetahuan yang bersifat nyata. Selain itu, bahan ajar video juga mampu dengan efektif menyampaikan materi yang bersifat proses atau prosedural. Bahan ajar video juga dapat digunakan untuk menambah pemahaman siswa tentang aplikasi dari konsep-konsep yang tengah dipelajari melalui bahan ajar utama atau modul. 
Berdasarkan penelitian Wahid, dkk (2006) dapat diketahui bahwa penggunaan internet (aplikasi teknologi informasi) cenderung dimanfaatkan khususnya untuk meningkatkan kapabilitas pendidikan secara personal, dan pengalaman internet, sekolah di Indonesia dan negara berkembang lainnya dapat memainkan peranan yang penting dalam mengembangkan sikap dan keahliannya untuk meningkatkan manfaat sosial dari penggunaan web.

\section{KESIMPULAN}

Hasil penelitian menunjukkan sikap mahasiswa memanfaatkan TIK dalam pembelajaran di UT yakni untuk tuton, websuplemen, I-TV dan LM Online berada pada kategori cukup baik. Hasil berikutnya mengenai latar belakang pendidikan mahasiswa berhubungan nyata dengan sikap mereka untuk menggunakan suplemen web dan I-TV. Hubunyan nyata juga terjadi antara wilayah tempat tinggal dengan sikap mahasiswa terhadap I-TV. Karakteristik ketersediaan fasilitas internet dan kepemilikan komputer berhubungan nyata dengan sikap mereka untuk menggunakan Tuton, websuplemen dan I-TV.

TIK dapat memberikan manfaat dalam bidang pendidikan khususnya produktivitas pembelajaran.Oleh karena itu, untuk meningkatkan akses mahasiswa terhadap layanan akademik online, diharapkan UT banyak menjalin kerja sama dengan penyedia jaringan internet di daerah.

\section{REFERENSI}

Belawati, T. (2003). Penerapan e-learning dalam pendidikan jarak jauh di indonesia dalam Durri Andriani, dkk (Ed). 2004. Cakrawala pendidikan: e-learning dalam pendidikan. Jakarta: Universitas Terbuka.

Iriani, D. (2010). Evaluasi Penyelenggaraan Sistem Ujian Online di UPBJJ UT Surabaya. Jurnal Pendidikan Terbuka dan Jarak Jauh; 2: 108.

Padmo, D. \& S. Julaeha. (2007). Tingkat Kepedulian dan Self Efficiancy Mahasiswa Universitas Terbuka terhadap E-Learning. Jurnal Pendidikan Terbuka dan Jarak Jauh; 8: 41.

Palupiningdyah dan Widiyanto. (2011). Strategi Peningkatan Kualitas Pembelajaran Melalui Pemanfaatan Increasing Learning Motivation ( ILMO). Ekplanasi Volume 6 Nomor 2 Edisi September 2011.

Pribadi, B.A. (2004). Pengembangan dan pemanfaatan bahan ajar puplemen dalam pendidikan tinggi jarak jauh dalam Asandhimitra, dkk (Ed).2004. Pendidikan tinggi jarak jauh. Jakarta: Universitas Terbuka.

Pustekkom. (2006). Teknologi Informasi dan Komunikasi (Information Communication Technology) Rencana strategis depertemen pendidikan nasional tahun 2005-2009 menuju pembangunan pendidikan nasional jangka panjang 2025.

Renstra UT 2010-2021. Jakarta: Universitas Terbuka.

Servaes, J. (2007). Harnessing the UN system into a common approach on communication for development. International Communication Gazette 2007; 69; 483.

Smeureanu, I, \& N. Isaila (2011). Information technology, support for innovation in education sciences. Jurnal procedia social and behavioral sciences, vol.15: 751. Diambil pada tanggal 17 April 2012 dari www.sciencedirect.

Sukarsih, Y. (2005). Pemanfaatan layanan UT Online di Institusi pendidikan jarak jauh. Jurnal pendidikan terbuka dan jarak jauh; vol. 6: 69.

Wahid F, Furuholt B, Kristiansen S. (2006). Internet for development? Patterns of use among internet café customers in Indonesia. Information Development 2006; 22; 278. 
Wahyono, S. B. \& Pujiriyanto. (2010). Analisis jalur terhadap tingkat melek teknologi informasi dan komunikasi (ICT literacy) pada mahasiswa FIP UNY. Laporan Penelitian Fakultas. Yogyakarta: Universitas Negeri Yogyakarta.

www.internetworldstats.com [diakses pada tanggal 27 Pebruari 2012].

Yuliana, E. \& Wardiny, T.M. (2011). Aksesibilitas dan intensitas mahasiswa dalam tutorial online (Kasus: Mahasiswa program studi agribisnis FMIPA-UT). Laporan penelitian madya kelembagaan. Tangerang Selatan: Universitas Terbuka. 